\title{
Testing shrinkage factors: comparison of methods and correlation with index properties of soils
}

\author{
Dorota Izdebska-Mucha $\cdot$ Emilia Wójcik
}

Received: 9 April 2012/Accepted: 6 December 2012/Published online: 18 January 2013

(C) The Author(s) 2013. This article is published with open access at Springerlink.com

\begin{abstract}
The paper presents a study on the shrinkage properties of three clay soils from Poland. Shrinkage limit, volumetric shrinkage and relative volumetric shrinkage were determined, tested according to PN-88/B-04481 (1988) and BS1377: Part 2 (1990) and correlated with the index properties of soils. The shrinkage limit was also calculated from Krabbe's (1958) equation. The results showed that shrinkage limit values obtained by the BS method are lower than those obtained using the PN method, but the values calculated from Krabbe's equation differ significantly. While no strong correlation was found between shrinkage limit and index soil parameters, linear relationships were obtained between volumetric shrinkage and initial moisture content, shrinkage range, plasticity index and clay content. Following multivariable regression analysis, the relative volumetric shrinkage was expressed as a function of plasticity index and moisture content. This function can be used to predict volumetric changes of the foundations based on the moisture content and material properties of the soil.
\end{abstract}

Keywords Volumetric shrinkage - Shrinkage limit . Clay soil $\cdot$ Shrinkage testing

Résumé L'article présente une étude sur les propriétés de retrait de trois sols argileux de Pologne. La limite de retrait, le retrait volumique et le retrait volumique relatif ont été déterminés à partir d'essais normalisés [PN-88/B-04481

\footnotetext{
D. Izdebska-Mucha $(\bowtie) \cdot$ E. Wójcik

Faculty of Geology, Institute of Hydrogeology and Engineering

Geology, University of Warsaw, Warsaw, Poland

e-mail:dim@uw.edu.pl

E. Wójcik

e-mail:wojcike@uw.edu.pl
}

(1988) et BS1377: Partie 2 (1990)] et corrélés avec les paramètres d'identification géotechnique des sols. La limite de retrait a également été calculée à partir de l'équation de Krabbe (1958). Les résultats ont montré que les valeurs des limites de retrait obtenues par la méthode BS sont inférieures à celles obtenues en utilisant la méthode PN, mais les valeurs calculées à partir de l'équation de Krabbe diffèrent de manière significative. Bien qu'aucune corrélation forte n'ait été trouvée entre la limite de retrait et les paramètres d'identification géotechnique du sol, des relations linéaires ont été obtenues entre le retrait volumique et la teneur en eau initiale, l'amplitude de retrait, l'indice de plasticité et la teneur en argile. A partir d'une analyse de régression multivariée, le retrait volumique relatif a été exprimé en fonction de l'indice de plasticité et de la teneur en eau. Cette fonction peut être utilisée pour prévoir les changements volumiques des sols basés sur la teneur en eau et les propriétés géotechniques des sols.

Mots clés Retrait volumique - Limite de retrait . Sol argileux $\cdot$ Mesures du retrait

\section{Introduction}

Expansiveness is the most important geotechnical problems with clay soils. The term expansiveness refers to volume changes-swelling and shrinkage-in clay soils due to changes in the moisture content. Such volume changes may cause settlement due to compression, postconsolidation settlement due to shrinkage, heave due to expansion and deformation due to shear stress. As a consequence, expansive soils affect the construction and stability of buildings, as described for example by Najder and Werno (1968), Kumor (1990, 2008), Jeż and Jeż (2006). 
The importance of this problem is reflected in the large number of international conferences held on the topic as well as the papers published in technical journals. While most studies of expansive soils focus on swelling, shrinkage has received less attention. According to Kumor (2008) the major issue in geotechnical practice is to predict afterconsolidation shrinkage settlements of expansive soils. The author proposed a general formula to evaluate volumetric shrinkage in relation to field moisture content changes but suggested that the moisture content should be considered jointly with the "material" properties of a soil.

It is generally believed that shrinkage and swelling correlate with plasticity and, in addition to the soil fabric, they depend on the same soil characteristics, such as mineralogical composition, particle size distribution, and type of adsorbed cations. It is also believed that there is a relationship between shrinkage and swelling, which has led to several classifications of swelling and expansiveness of clay soils where shrinkage parameters such as shrinkage limit, linear shrinkage and shrinkage index are used as criteria (e.g. Altmeyer 1955; Holtz 1959; Rangantham and Satanarayna 1965; Raman 1967; Tountoungi 1988). On the other hand, some authors have proved experimentally that there is no consistent relationship between shrinkage and swelling, or between shrinkage limit and plasticity or clay content (Chen and Ma 1987; Sridharan and Prakash 1998).

This paper presents a study on the shrinkage properties of natural clay soils from Poland, which differ in genesis, composition and plasticity. It contributes to the discussion on a correlation between shrinkage limit and other index parameters of soils. It also provides a comparison and evaluation of shrinkage testing in terms of accuracy, difficulty and consistency between the methods. Finally, an empirical relationship between the volumetric shrinkage, moisture content and plasticity index of soils is proposed.

\section{Materials and methods}

Three genetic types of natural clay soils which commonly form the founding material for construction in Poland were used in this investigation: glacial tills (14 samples), alluvial clay soils (4 samples) and Mio-Pliocene clays (16 samples).

The following basic parameters were determined for all soils (see Table 1):

1. plastic limit $w_{\mathrm{p}}$ according to BS1377: Part 2 (1990).

2. liquid limit $w_{\mathrm{L}}$ by cone penetration method (Ele, UK) according to BS1377: Part 2 (1990).

3. particle density $\rho_{\mathrm{s}}$ in a helium pycnometer (Micromeritics, USA) on the $<2 \mathrm{~mm}$ soil fraction.

4. clay content $\mathrm{Cl}$, by hydrometer analysis according to BS1377: Part 2 (1990).
5. dry density $\rho_{\mathrm{d}}$, as weight per unit volume after drying at $105{ }^{\circ} \mathrm{C}$. This parameter was used to determine the shrinkage limit according to PN-88/B-04481 (1988) as described below.

Plotted on the plasticity chart (Fig. 1) both glacial tills and alluvial soils proved to be clays of low and medium plasticity (CL, CM). The Mio-Pliocene soils fell into several categories: most of the samples being clays of high to extremely high plasticity $(\mathrm{CH}, \mathrm{CV}, \mathrm{CE})$ with three samples falling below the A-line and classified as silts of high to extremely high plasticity (MH/MV, ME).

Three methods were applied to determine and compare the shrinkage limit $\left(w_{\mathrm{s}}\right)$ of the analysed soils:

1. The first method is given in BS1377: Part 2 (1990): 6.3 (referred to as BS). In this method a series of readings of volume and corresponding mass are taken as the soil specimen is allowed to dry slowly, until no further change in volume is recorded. The specimen is then dried in an oven at $105^{\circ} \mathrm{C}$ and final weight and volume measurements taken. The shrinkage limit $w_{\mathrm{s}}$ is determined from a graph of unit volume $/ 100 \mathrm{~g}$ of dry soil against moisture content.

This test is also a method for the measurement of volumetric shrinkage $V_{\mathrm{s}}$, which is calculated from the equation: $V_{\mathrm{s}}=\left(w-w_{\mathrm{s}}\right) / R_{\mathrm{s}} ;$

where $w$ is the initial moisture content $(\%), w_{\mathrm{s}}$ is shrinkage limit (\%), and $R_{\mathrm{S}}$ is the shrinkage ratio (-),

$R_{\mathrm{s}}=m_{\mathrm{d}} /\left(\rho_{\mathrm{w}} \times V_{\mathrm{d}}\right)$

where $m_{\mathrm{d}}$ is the soil mass after drying at $105{ }^{\circ} \mathrm{C}(\mathrm{g}), V_{\mathrm{d}}$ the soil volume after drying at $105^{\circ} \mathrm{C}\left(\mathrm{cm}^{3}\right)$, and $\rho_{\mathrm{w}}$ is the water density $\left(1 \mathrm{Mg} / \mathrm{m}^{3}\right)$.

The volume measurements were taken by immersing the soil specimen in mercury, using the Wykeham Farrance apparatus WF 2/756 (UK). The tests were performed on remolded samples of initial moisture content $\left(w_{0}\right)$ corresponding to the plastic state of the soil.

2. The second method is given in the Polish Standard PN88/B-04481 (1988) (referred to as PN). Here the shrinkage limit $w_{\mathrm{s}}$ is calculated from the equation:

$w_{\mathrm{s}}=\left[\left(\rho_{\mathrm{w}} / \rho_{\mathrm{d}}\right)-\left(\rho_{\mathrm{w}} / \rho_{\mathrm{s}}\right)\right] \times 100$

where $\rho_{\mathrm{w}}$ is the water density $\left(1 \mathrm{Mg} / \mathrm{m}^{3}\right), \rho_{\mathrm{s}}$ the particle density $\left(\mathrm{Mg} / \mathrm{m}^{3}\right)$, and $\rho_{\mathrm{d}}$ is the dry density of a soil after drying at $105{ }^{\circ} \mathrm{C}\left(\mathrm{Mg} / \mathrm{m}^{3}\right)$,

$\rho_{\mathrm{d}}=m_{\mathrm{d}} / V_{\mathrm{d}}$

where $m_{\mathrm{d}}$ is the soil mass after drying at $105{ }^{\circ} \mathrm{C}(\mathrm{g})$ and $V_{\mathrm{d}}$ is the soil volume after drying at $105{ }^{\circ} \mathrm{C}\left(\mathrm{cm}^{3}\right)$. 
Table 1 Properties of the soils studied

\begin{tabular}{|c|c|c|c|c|c|c|c|}
\hline $\begin{array}{l}\text { Soil } \\
\text { no }\end{array}$ & Soil & $\begin{array}{l}\text { Particle density } \\
\rho_{\mathrm{s}}\left(\mathrm{Mg} / \mathrm{m}^{3}\right)\end{array}$ & $\begin{array}{l}\text { Dry density } \\
\rho_{\mathrm{d}}\left(\mathrm{Mg} / \mathrm{m}^{3}\right)\end{array}$ & $\begin{array}{l}\text { Plastic limit } \\
w_{\mathrm{p}}(\%)\end{array}$ & $\begin{array}{l}\text { Liquid limit } \\
w_{\mathrm{L}}(\%)\end{array}$ & $\begin{array}{l}\text { Plasticity } \\
\text { index } I_{\mathrm{p}}(\%)\end{array}$ & $\begin{array}{l}\text { Clay content } \\
\mathrm{Cl}(\%)\end{array}$ \\
\hline 1 & \multirow[t]{14}{*}{ Glacial tills } & 2.68 & 2.08 & 14.3 & 25.8 & 11.5 & 24 \\
\hline 2 & & 2.70 & 2.04 & 12.4 & 23.6 & 11.2 & 27 \\
\hline 3 & & 2.70 & 2.03 & 12.8 & 24.0 & 11.2 & 25 \\
\hline 4 & & 2.71 & 2.05 & 13.0 & 23.3 & 10.3 & 24 \\
\hline 5 & & 2.69 & 2.04 & 13.5 & 23.5 & 10.0 & 24 \\
\hline 6 & & 2.61 & 1.92 & 12.2 & 28.8 & 16.6 & 20 \\
\hline 7 & & 2.66 & 1.85 & 15.0 & 35.1 & 20.1 & 25 \\
\hline 8 & & 2.67 & 1.85 & 19.1 & 40.9 & 21.8 & 29 \\
\hline 9 & & 2.69 & 1.84 & 19.4 & 40.0 & 20.6 & 28 \\
\hline 10 & & 2.70 & 1.85 & 22.5 & 45.9 & 23.4 & 50 \\
\hline 11 & & 2.69 & 1.85 & 21.0 & 43.3 & 22.3 & 55 \\
\hline 12 & & 2.66 & 2.02 & 14.0 & 36.6 & 22.6 & 29 \\
\hline 13 & & 2.70 & 1.99 & 12.0 & 20.6 & 8.6 & 21 \\
\hline 14 & & 2.67 & 2.00 & 13.7 & 19.3 & 5.6 & 18 \\
\hline 15 & \multirow[t]{4}{*}{ Alluvial soils } & 2.68 & 2.09 & 23.4 & 48.0 & 24.6 & 15 \\
\hline 16 & & 2.69 & 2.08 & 19.0 & 38.2 & 19.2 & 27 \\
\hline 17 & & 2.66 & 1.88 & 17.9 & 26.0 & 8.1 & 9 \\
\hline 18 & & 2.68 & 1.89 & 18.9 & 35.8 & 16.9 & 13 \\
\hline 19 & \multirow[t]{16}{*}{ Mio-Pliocene clays } & 2.81 & 2.05 & 28.6 & 78.9 & 50.3 & 88 \\
\hline 20 & & 2.79 & 2.05 & 30.5 & 69.6 & 39.1 & 83 \\
\hline 21 & & 2.80 & 2.03 & 29.3 & 68.1 & 38.8 & 73 \\
\hline 22 & & 2.77 & 2.18 & 19.6 & 54.4 & 34.8 & 70 \\
\hline 23 & & 2.78 & 2.13 & 18.9 & 52.8 & 33.9 & 67 \\
\hline 24 & & 2.68 & 1.80 & 34.0 & 87.0 & 53.0 & 85 \\
\hline 25 & & 2.72 & 1.93 & 41.0 & 96.0 & 55.0 & 80 \\
\hline 26 & & 2.69 & 1.94 & 35.0 & 83.0 & 48.0 & 72 \\
\hline 27 & & 2.71 & 1.96 & 22.5 & 69.5 & 47.0 & 63 \\
\hline 28 & & 2.70 & 1.97 & 39.3 & 69.9 & 30.6 & 30 \\
\hline 29 & & 2.70 & 1.92 & 31.1 & 70.1 & 39.0 & 70 \\
\hline 30 & & 2.72 & 1.82 & 30.3 & 83.0 & 52.7 & 80 \\
\hline 31 & & 2.71 & 1.81 & 32.3 & 99.0 & 66.7 & 65 \\
\hline 32 & & 2.71 & 1.70 & 43.6 & 91.7 & 48.1 & 90 \\
\hline 33 & & 2.68 & 1.90 & 27.6 & 68.2 & 40.6 & 62 \\
\hline 34 & & 2.69 & 1.85 & 25.4 & 64.4 & 39.0 & 61 \\
\hline
\end{tabular}

In order to gain the best comparison between these two methods, the dry density was determined for the same soil specimens by the BS shrinkage limit tests and calculated on the basis of measurements taken during those tests $\left(m_{\mathrm{d}}, V_{\mathrm{d}}\right)$.

3. The third method to assess the shrinkage limit $w_{\mathrm{s}}$ was to calculate it from the empirical relationship given by Krabbe in 1958 (Schultze and Muhs 1967):

$w_{\mathrm{s}}=w_{\mathrm{L}}-1.25 \times I_{\mathrm{p}}$

where $w_{\mathrm{L}}$ is the plastic limit $(\%)$ and $I_{\mathrm{p}}$ is the plasticity index (\%). In addition to the shrinkage limit $w_{\mathrm{s}}$ and volumetric shrinkage $V_{\mathrm{s}}$ also the relative volumetric shrinkage $V_{\mathrm{p}}$ was calculated from the general formula:

$V_{\mathrm{p}}=\left[\left(V_{0}-V_{\mathrm{d}}\right) / V_{0}\right] \times 100 \%$

where $V_{0}$ is the initial soil volume $\left(\mathrm{cm}^{3}\right)$ and $V_{\mathrm{d}}$ is the soil volume after drying $\left(\mathrm{cm}^{3}\right)$.

$V_{0}, V_{\mathrm{d}}$ values used for calculation were obtained during the BS shrinkage limit testing, which means that $V_{0}$ corresponded to the plastic state of the soil and $V_{\mathrm{d}}$ was the volume of the soil after drying at $105^{\circ} \mathrm{C}$.

Shrinkage index SI was calculated from the equation (Rangantham and Satanarayana 1965): 
Fig. 1 Plasticity chart for the soils studied

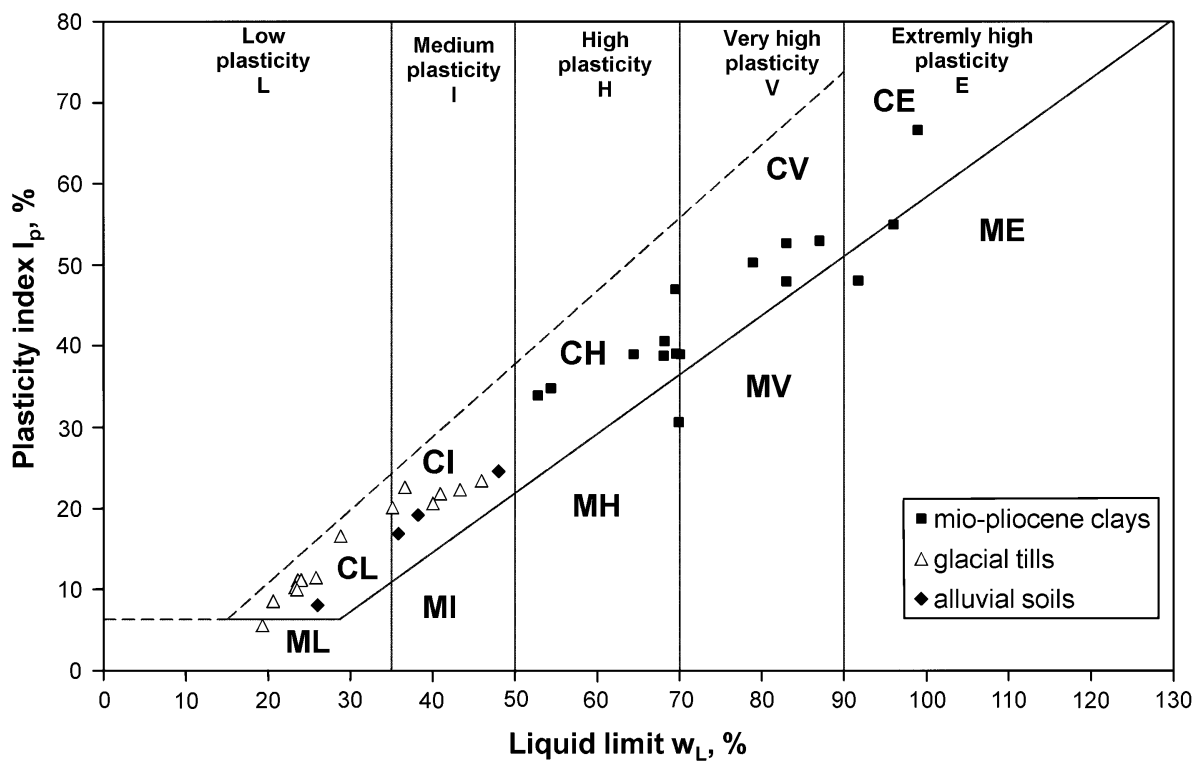

$\mathrm{SI}=w_{\mathrm{L}}-w_{\mathrm{S}}$

where $w_{\mathrm{L}}$ is the plastic limit $(\%)$ and $w_{\mathrm{S}}$ is the shrinkage limit (\%).

All shrinkage tests were performed on remolded soil samples; according to Mitchell (1993) the remolded samples show greater shrinkage than the undisturbed soils.

To define the relationships between the experimentally determined parameters, the least squares method was used. A statistical analysis was performed using the Statistica software $\left(\right.$ StatSoft $\left.{ }^{\circledR}\right)$.

\section{Results and discussion}

Shrinkage limit and volumetric shrinkage

The shrinkage properties of the tested Mio-Pliocene clays, alluvial soils and glacial tills are summarized in Table 2. They confirm the high expansive properties of the Mio-Pliocene clays and indicate lower average values of volumetric shrinkage $\left(V_{\mathrm{s}}\right.$ and $V_{\mathrm{p}}$ ) and shrinkage limit for the alluvial soils and glacial tills. A comparison of the shrinkage limit values obtained from various methods is shown in Fig. 2, which indicates that the shrinkage limit values obtained using the BS method are lower than the results using PN. The difference between the average values, however, is not very high, ranging from 1 to $4 \%$.

The main findings, therefore, are:

1. As the methodology of shrinkage testing according to British Standard is relatively complex and time consuming, it seems reasonable and more convenient to apply the Polish Standard method for this purpose, albeit the results are slightly higher.
2. As shrinkage limit is one of the criteria of soil expansiveness (e.g. Altmeyer 1955; Holtz 1959; Tountoungi 1988), the difference in the shrinkage limit values obtained from British and Polish methods can lead to different soil classifications. The higher the values of the shrinkage limit, the lower the degree of soil expansiveness. Therefore, the evaluation of soil expansiveness based on the shrinkage limit values determined according to BS provides a greater margin of foundation safety because it assumes less favorable conditions.

Shrinkage limit values calculated from Krabbe's formula generally differ significantly from the two latter methods and show no consistent relationship with them. A correction of Krabbe's equation was attempted, but the function obtained $w_{\mathrm{s}}=f\left(I_{\mathrm{p}}, w_{\mathrm{L}}\right)$ does not fit well with the analysed data set:

$w_{\mathrm{s}}=0.310 \times w_{\mathrm{L}}-0.352 \times I_{\mathrm{p}}+5.621 \pm 2.417$

where $R=0.694 ; w_{\mathrm{s}}$ acc. $\mathrm{BS}$.

From this study therefore the suitability of Krabbe's equation for shrinkage limit determination is questionable.

Relationship between the shrinkage limit/volumetric shrinkage and index parameters

An attempt was made to determine the relationship between the shrinkage limit and other index parameters of the studied soils. Figures 3, 4 and 5 show the variation of shrinkage limit and clay content, liquid limit and plasticity index, respectively. The results indicate that no satisfactory correlation exists.

Similar results were obtained by Sridharan and Prakash (1998), who studied the mechanism controlling the 
Table 2 Moisture content, shrinkage parameters and expansiveness of the soils studied

\begin{tabular}{|c|c|c|c|c|c|c|c|c|c|}
\hline \multirow[t]{2}{*}{$\begin{array}{l}\text { Soil } \\
\text { no. }\end{array}$} & \multirow[t]{2}{*}{ Soil } & \multirow[t]{2}{*}{$\begin{array}{l}\text { Initial moisture } \\
\text { content } w_{0}(\%)\end{array}$} & \multicolumn{3}{|c|}{ Shrinkage limit $w_{\mathrm{s}}(\%)$} & \multicolumn{2}{|c|}{$\begin{array}{l}\text { Volumetric } \\
\text { shrinkage }(\%)\end{array}$} & \multirow[t]{2}{*}{$\begin{array}{l}\text { Shrinkage } \\
\text { index } \mathrm{SI}^{\mathrm{a}}(\%)\end{array}$} & \multirow[t]{2}{*}{$\begin{array}{l}\text { Degree of } \\
\text { expansion }^{b}\end{array}$} \\
\hline & & & BS & $\mathrm{PN}$ & Krabbe (1958) & $V_{\mathrm{s}}$ & $V_{\mathrm{p}}$ & & \\
\hline 1 & \multirow[t]{15}{*}{ Glacial tills } & 15.2 & 7.0 & 10.8 & 11.4 & 3.9 & 9.3 & 18.8 & \multirow[t]{5}{*}{ Low } \\
\hline 2 & & 16.7 & 9.6 & 12.0 & 9.6 & 3.5 & - & 14.0 & \\
\hline 3 & & 15.9 & 8.5 & 12.2 & 10.0 & 3.7 & - & 15.5 & \\
\hline 4 & & 16.7 & 8.0 & 11.9 & 10.4 & 4.2 & 12.1 & 15.3 & \\
\hline 5 & & 16.5 & 8.2 & 11.8 & 11.0 & 4.1 & 12.0 & 15.3 & \\
\hline 6 & & 15.2 & 8.1 & 13.8 & 8.1 & 5.7 & 10.7 & 20.7 & \multirow[t]{4}{*}{ Medium } \\
\hline 7 & & 16.7 & 11.4 & 16.5 & 10.0 & 4.3 & 11.3 & 23.7 & \\
\hline 8 & & 15.9 & 14.1 & 16.6 & 13.7 & 4.6 & 12.4 & 26.8 & \\
\hline 9 & & 16.7 & 11.9 & 17.2 & 14.3 & 6.1 & 12.5 & 28.1 & \\
\hline 10 & & 16.5 & 15.5 & 17.0 & 16.7 & 5.9 & 16.8 & 30.4 & High \\
\hline 11 & & 19.0 & 16.1 & 16.9 & 15.4 & 5.6 & 16.6 & 27.2 & \multirow[t]{2}{*}{ Medium } \\
\hline 12 & & 19.3 & 8.7 & 11.9 & 8.4 & 3.1 & 13.0 & 27.9 & \\
\hline 13 & & 15.7 & 5.8 & 13.2 & 9.9 & 5.0 & 6.0 & 14.8 & \multirow[t]{2}{*}{ Low } \\
\hline 14 & & 15.9 & 9.6 & 12.5 & 12.3 & 3.1 & 9.6 & 9.7 & \\
\hline Ave & & 18.9 & 10.2 & 13.9 & 11.5 & 4.5 & 11.9 & 20.6 & - \\
\hline Star & deviation & 4.1 & 3.2 & 2.4 & 2.6 & 1.0 & 3.0 & 6.7 & - \\
\hline 15 & \multirow{5}{*}{ Alluvial soils } & 25.3 & 13.6 & 10.5 & 17.3 & 5.6 & 18.5 & 34.4 & High \\
\hline 16 & & 25.5 & 13.0 & 10.9 & 14.2 & 6.0 & 18.4 & 25.2 & Medium \\
\hline 17 & & 24.6 & 10.0 & 15.6 & 15.9 & 7.8 & 18.0 & 16.0 & Low \\
\hline 18 & & 24.7 & 12.8 & 15.6 & 14.7 & 6.3 & 18.0 & 23.0 & Medium \\
\hline Average & & 25.0 & 12.4 & 13.2 & 15.5 & 6.4 & 18.2 & 24.7 & - \\
\hline \multicolumn{2}{|c|}{ Standard deviation } & 0.5 & 1.6 & 2.8 & 1.4 & 0.9 & 0.2 & 7.6 & - \\
\hline 19 & \multirow[t]{18}{*}{ Mio-Pliocene clays } & 36.5 & 9.1 & 13.2 & 16.0 & 13.4 & 32.2 & 69.8 & Very high \\
\hline 20 & & 35.3 & 10.9 & 12.9 & 20.7 & 11.9 & 31.7 & 58.7 & \multirow[t]{4}{*}{ High } \\
\hline 21 & & 32.3 & 10.0 & 13.5 & 19.6 & 11.0 & 27.8 & 58.1 & \\
\hline 22 & & 27.9 & 5.6 & 9.8 & 10.9 & 10.2 & 27.0 & 48.8 & \\
\hline 23 & & 30.5 & 7.2 & 11.0 & 10.4 & 10.9 & 27.2 & 45.6 & \\
\hline 24 & & 40.3 & 16.0 & 18.2 & 20.8 & 13.5 & 30.1 & 71.0 & \multirow[t]{3}{*}{ Very high } \\
\hline 25 & & 45.8 & 13.5 & 15.0 & 27.3 & 16.7 & 37.8 & 82.5 & \\
\hline 26 & & 40.4 & 13.8 & 14.4 & 23.0 & 13.7 & 33.4 & 69.2 & \\
\hline 27 & & 44.0 & 12.3 & 14.1 & 10.8 & 16.2 & 37.8 & 57.2 & \multirow[t]{3}{*}{ High } \\
\hline 28 & & 45.8 & 13.8 & 13.7 & 31.7 & 16.2 & 39.6 & 56.1 & \\
\hline 29 & & 38.6 & 14.2 & 15.0 & 21.4 & 12.7 & 32.0 & 55.9 & \\
\hline 30 & & 58.2 & 15.3 & 18.2 & 17.1 & 23.6 & 44.8 & 67.7 & \multirow[t]{3}{*}{ Very high } \\
\hline 31 & & 62.2 & 13.9 & 18.3 & 15.6 & 26.7 & 44.5 & 85.1 & \\
\hline 32 & & 68.1 & 19.0 & 21.9 & 31.6 & 28.9 & 45.5 & 72.7 & \\
\hline 33 & & 45.3 & 12.0 & 15.3 & 17.4 & 17.5 & 39.3 & 56.2 & \multirow[t]{2}{*}{ High } \\
\hline 34 & & 44.6 & 13.4 & 16.9 & 15.7 & 16.9 & 34.6 & 51.0 & \\
\hline Ave & & 43.5 & 12.5 & 15.1 & 19.4 & 16.3 & 35.3 & 62.9 & - \\
\hline Star & & 11.2 & 3.3 & 3.0 & 6.6 & 5.6 & 6.2 & 11.6 & - \\
\hline
\end{tabular}

${ }^{\text {a }} \mathrm{SI}=w_{\mathrm{L}}-w_{\mathrm{s}}$, where $w_{\mathrm{s}}$ acc. to $\mathrm{BS}$

b Classification according to Rangantham and Satanarayana (1965) 
Fig. 2 Shrinkage limit of soils tested by three methods



shrinkage limit on a group of natural soils and pure clays. The authors concluded that the shrinkage limit is governed by particle size distribution rather than by the plasticity characteristics of the soil.

Volumetric shrinkage depends on several soil characteristics such as: mineralogical composition, particle size distribution, texture, structure, exchangeable cations, organic matter content and, last but not least, the range of moisture content changes observed in the process of shrinkage. This change in moisture content can be expressed by the shrinkage range, defined as the difference between initial and shrinkage limit moisture content $w_{0}-w_{\mathrm{s}}$ (after Head 1992).

Relationships with a high linear correlation coefficient have been found between volumetric shrinkage $V_{\mathrm{s}}$ and the relative volumetric shrinkage $V_{\mathrm{p}}$ and the initial moisture content $w_{0}$, shrinkage range, plasticity index $I_{\mathrm{p}}$ and clay content and illustrated in Figs. 6, 7, 8, 9 respectively.
Kumor (2007) points out that from the practical point of view, to reliably predict the volume changes of the subsoil, the multivariable relationship between volumetric shrinkage and moisture content as well as the material properties of the soil (e.g. Atterberg limits, clay content) should be defined. In view of this, a statistical analysis was made between volumetric shrinkage $\left(V_{\mathrm{p}}\right.$ and $\left.V_{\mathrm{s}}\right)$ and index properties of the soils using the least squares method. A linear relationship was found with the correlation coefficient $R=0.968$ :

$V_{\mathrm{p}}=0.629 w_{0}+0.191 \times I_{\mathrm{p}}-1.659 \pm 3.166$

with $\alpha=0.95$.

With respect to the problem raised by Kumor (2007), the relationship between $V_{\mathrm{p}}$ and shrinkage range $\left(w_{0}-w_{\mathrm{s}}\right)$ is also noteworthy (see Fig. 7): 
Fig. 3 Variation of shrinkage limit and clay content

Fig. 4 Variation of shrinkage limit and liquid limit

Fig. 5 Variation of shrinkage limit and plasticity index
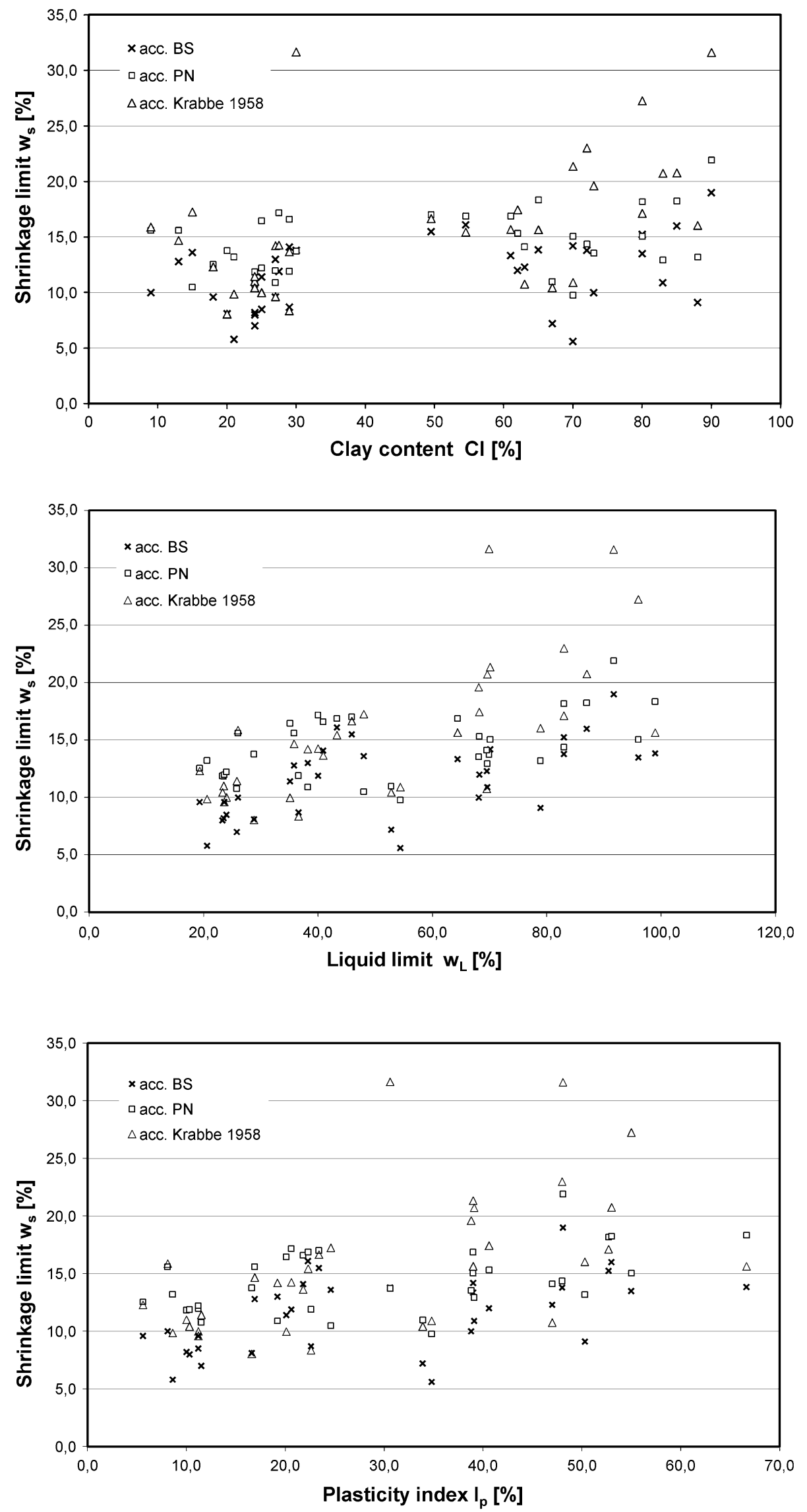
Fig. 6 Correlation between volumetric shrinkage and moisture content

Fig. 7 Correlation between volumetric shrinkage and shrinkage range

Fig. 8 Correlation between volumetric shrinkage and plasticity index
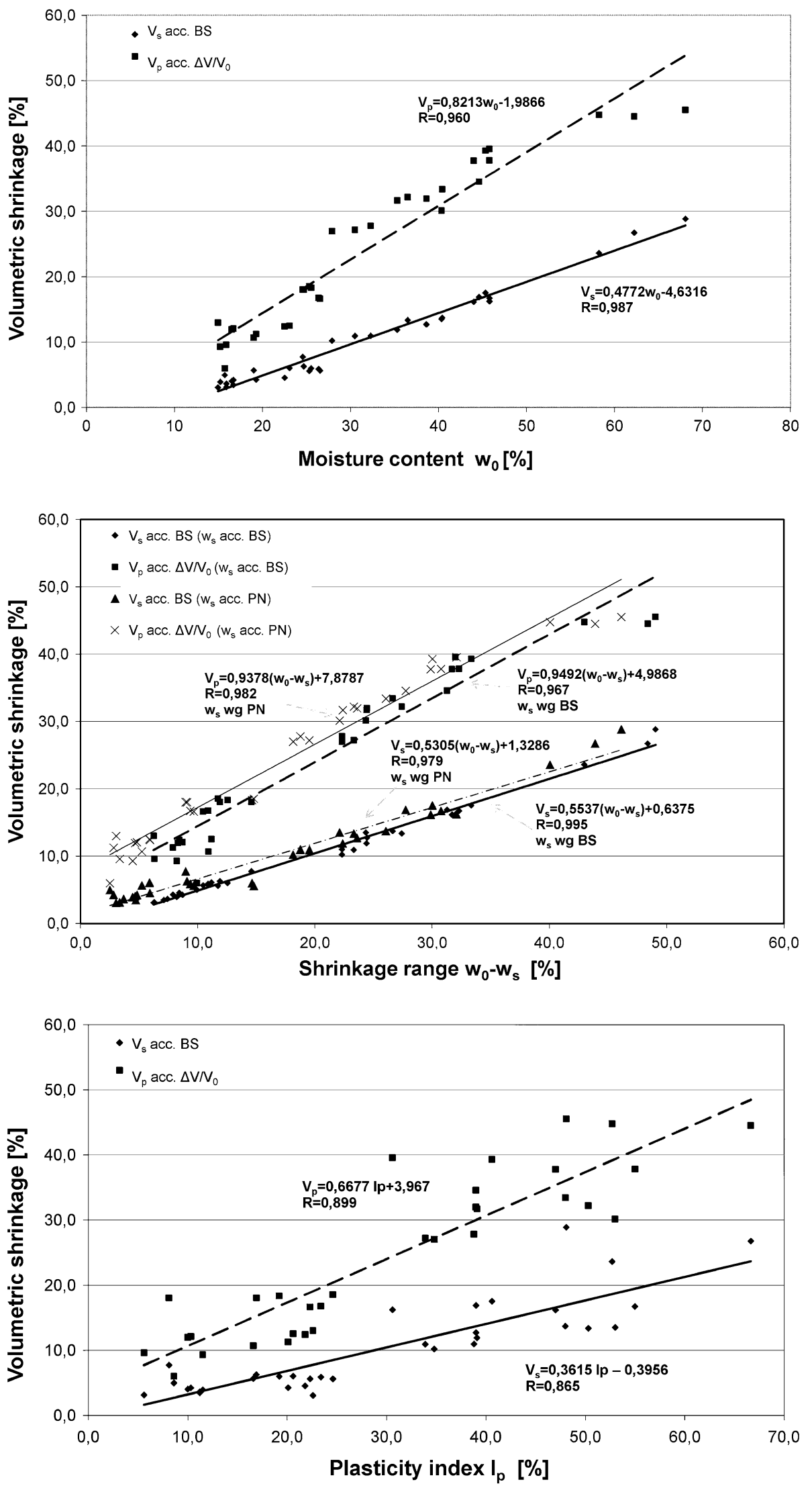
Fig. 9 Correlation between volumetric shrinkage and clay content

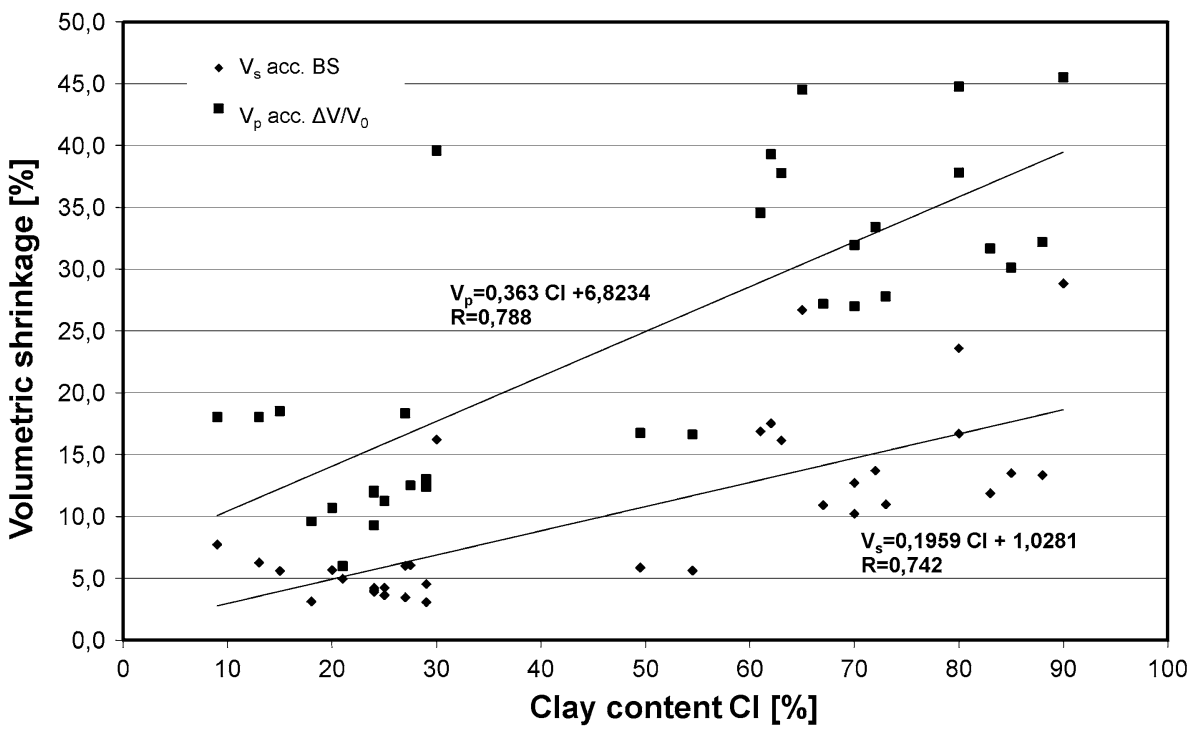

$V_{\mathrm{p}}=0.949\left(w_{0}-w_{\mathrm{s}}\right)+4.987$

where $R=0.967 ; w_{\mathrm{s}}$ acc. $\mathrm{BS}$.

$V_{\mathrm{p}}=0.938\left(w_{0}-w_{\mathrm{s}}\right)+7.879$

where $R=0.982 ; w_{\mathrm{s}}$ acc. $\mathrm{PN}$.

Equations (10) and (11) can be used to predict the maximum volume changes in ground with a given initial moisture content $\left(w_{0}\right)$ as a result of shrinkage.

\section{Conclusions}

1. The analysis of shrinkage properties carried out for Mio-Pliocene clays, glacial tills and alluvial clay soils revealed that the shrinkage limit $\left(w_{\mathrm{s}}\right)$ and volumetric shrinkage ( $V_{\mathrm{s}}$ and $V_{\mathrm{p}}$ ) decreased in the sequence: MioPliocene clays $>$ alluvial soils $>$ glacial tills.

2. A comparison of three methods of obtaining the shrinkage limit indicated that shrinkage limit values determined according to BS1377: Part 2 (1990): 6.3 are lower than those from the PN-88/B-04481 (1988) method; the average values varying by $1-4 \%$. However the shrinkage limit values calculated from Krabbe's (1958) equation differ significantly and are inconsistent with results yielded by the former methods.

3. The complexity of testing procedure is higher for the British Standard method, but the results provide a greater margin of safety when used in the classification of expansive soils.

4. A statistical analysis of the relationships between the shrinkage parameters and index properties of the soils showed that no satisfactory correlation exists between shrinkage limit and clay content, liquid limit and plasticity index. Relationships with a high linear correlation coefficient were found between volumetric shrinkage $V_{\mathrm{s}}$, relative volumetric shrinkage $V_{\mathrm{p}}$ and initial moisture content, shrinkage range, plasticity index and clay content.

5. A multidimensional regression analysis was carried out and a new predictive equation for relative volumetric shrinkage $V_{\mathrm{p}}$ is proposed:

$V_{\mathrm{p}}=0.629 w_{0}+0.191 \times I_{\mathrm{p}}-1.659 \pm 3.166$.

For practical purposes, this equation can be used to predict volumetric shrinkage changes in the subsoil, taking into account the soil moisture content $\left(w_{0}\right)$ as well as the "material properties" of the soil, expressed by the plasticity index $\left(I_{\mathrm{p}}\right)$ - parameters easily and commonly tested in geological engineering practice.

Acknowledgments The authors would like to acknowledge Professor Stanisław Matysiak (University of Warsaw, Faculty of Geology) for the valuable comments to improve the article and Dr Paweł Wolff (Polish Academy of Sciences, Institute of Mathematics) for help in statistical analysis of the results.

Open Access This article is distributed under the terms of the Creative Commons Attribution License which permits any use, distribution, and reproduction in any medium, provided the original author(s) and the source are credited.

\section{References}

Altmeyer WT (1955) Discussion on engineering properties of expansive clays. Proc Am Soc Civ Eng 81(658):17-19

BS1377: Part 2 (1990) Methods of testing soils for civil engineering purposes. British Standards Institution, London 
Chen FH, Ma GS (1987) Swelling and shrinkage behaviour of expansive soils. In: Proceedings of the sixth international conference on expansive soils, vol 1. New Delhi, pp 127-129

Head KH (1992) Manual of soil laboratory testing 1: soil classification and compaction tests. Pentech Press, London

Holtz WG (1959) Expansive clays-properties and problems. Q J Colo Sch Min 54(4):89-125

Jeż J, Jeż T (2006) O awariach budynków posadowionych na iłach poznańskich. Inżynieria i Budownictwo 62(3):135-137

Kumor MK (1990) Awarie budynków posadowionych na ekspansywnych iłach trzeciorzędowych w Bydgoszczy. Przegląd Budowlany 11: $471-476$

Kumor MK (2007) Wybrane problemy skurczu iłów ekspansywnych rejonu Bydgoszczy. Zeszyty Naukowe Politechniki Śląskiej Seria: Budownictwo 111:247-254

Kumor MK (2008) Selected geotechnical problems of expansive clays in the area of Poland. Archit Civ Eng Environ 1(4):75-92

Mitchell JK (1993) Fundamentals of soil behavior. John Wiley, New York, Chichester, Brisbane, Toronto, Singapore
Najder J, Werno W (1968) The effect of climatic fluctuations on displacement of buildings founded on Pliocene clays. Stavebnicky Casopis 2:83-94

PN-88/B-04481 (1988) Grunty budowlane. Badania próbek gruntu. Polski Komitet Normalizacji, Miar i Jakości

Raman V (1967) Identification of expansive soils from the plasticity index and the shrinkage index data. Indian Eng 11(1):17-22

Rangantham GV, Satanarayana B (1965) A rational method of predicting swelling potential for compacted expansive soils. Proceeding of the 6th ICSMFE, vol 1. Montreal, pp 92-96

Schultze E, Muhs H (1967) Bodenuntersuchungen fur Ingenieurbauten. Springer Verlag, Berlin/Heidelberg/New York

Sridharan A, Prakash K (1998) Mechanism controlling the shrinkage limit of soils. Geotech Test J GTJODJ 21(3):240-250

Tountoungi A (1988) Expansion soil in Syria. In: Proceeding of the international conference on engineering problems of regional soils. Beijing, pp 413-714 